\title{
Short-term Economic Indicators, Stock Market Indexes and Indian Oil and Gas Stocks Returns
}

\author{
Rama Krishna Yelamanchili $P h D$ \\ Associate Professor of Finance \\ Department of Finance and Accounting \\ ICFAI Business School, IFHE-Hyderabad, India \\ E-mail: yrk@ibsindia.org
}

\begin{abstract}
In this paper we examine the causal relationship between short term economic indicators, stock market indexes and oil and gas stocks returns. We postulate that economic indicators positively and significantly cause and predict stock market indexes and oil and gas stock returns in short run. In addition, we posit that stock market indexes cause and predict oil and gas stock returns in short run. To test our hypotheses we chose four short-term economic indicators, two stock market indexes, and $\mathrm{IO}$ oil and gas companies. Our results indicate that there is no causal relationship between both short-term economic indicators and stock market indexes, and between short-term economic indicators and oil and gas stock returns. However, we receive support to one of our hypotheses that stock market indexes cause oil and gas stock returns. This causation is contemporaneous only and we observe that stock market indexes lack short-term predictive power of oil and gas stock returns. We conclude that investors need to be vigilant in considering coincident indicators as explanatory variables to predict stock returns. We suggest that stock market indexes are helpful to predict contemporaneous returns but not future returns of oil and gas stocks.
\end{abstract}

Keywords: Industrial Production, Oil Companies, Public Sector Undertakings, Predictive Analysis, Stock Markets.

JEL Classification: BI, C32, D4, G2.

\section{Introduction}

Traditionally, stock market index is viewed as a leading economic indicator and Index of Industrial Production (IIP) is viewed as a coincident or contemporaneous economic indicator. Few studies examine the causal relationship between stock market index and industrial production. Some argue that industrial production causes stock market movements, while others argue that stock market movements cause industrial production. We notice that most of the studies examine the relationship between economic factors and stock market movements rather than analyzing the influence of economic factors on individual stocks. We observe that there is limited research that examines the causal relationship between index of industrial production, stock market index, and individual stock returns. Therefore, this paper attempts to see whether stock returns can be explained with economic indicators and stock market indexes, and also to see whether stock returns can be predicted with those economic indicators and stock market indexes. It can be seen that industrial production increases during economic expansion and decreases during recession and thus change in industrial production would signal a change in economy. Similarly, stock market indexes reflect investors' current and future expectations about companies' performance. A positive movement in stock market represents investors optimistic outlook, and a negative movement indicates investors' pessimistic outlook. Our proposition is that high industrial production raise companies sales and profits, enhances investors optimism and leads to positive movement in stock market which rightly result in rise in stock returns. We postulate that stock returns are influenced by stock market movements and also by IIP which constitute the aggregate of manufacturing, mining, and electricity production.

This paper assumes significance in the light that India is the world's third largest consumer of primary energy and one of the fastest growing economies in the world. India produces less than one per cent of the world's crude oil, however, consumes nearly five per cent of the world's crude oil production. India imports 80 per cent of its crude oil. The oil and gas industry is among the eight core industries in India and plays main role in inducing decision making for all the other important industries of the economy. As a growing economy India's appetite for energy is also growing. In addition, as Indian households generating higher disposable incomes, there is significant boost in vehicle sales, transportation, tourism, and consumer goods. It is perceived that there exists a strong correlation between oil and gas companies' financial performance and the IIP, which is largely driven by economic activity. It is also observed that in the recent past there is a spurt in India's natural gas consumption and natural gas imports. Natural gas is seen to dominate the mainstay sectors of fertilizers, power, petrochemicals, steel, manufacturing industries, consumer goods manufacturers, domestic LPG and households. India's economic growth is closely related to energy demand. Therefore the need for oil and gas is projected to grow more, thereby making the sector quite favorable for investment. 
In this paper, we argue that short-term economic performance indicators will influence stock market movements and stock returns. We also propose that short-term economic indicators and stock market indexes predict stock returns in short run. To examine our hypotheses we chose oil and gas stocks. We expect that positive economic indicators reflect increased business activity which in turn creates demand for oil and gas products because majority of industries directly or indirectly consume oil and gas in their production, operations and distribution of goods and services. Furthermore, a high economic activity indicates higher income to workforce, which in turn boosts sales of certain goods and services like automobile, transportation etc., which in turn affect the financial performance of oil and gas stocks and their stock returns. In this paper we investigate the causal relationship between four short-term economic performance indicators namely, IIP, manufacturing index, mining index, electricity index, and two broad market indexes namely S \& P BSE SENSEX, and stock market Oil and Gas sectorial index with 10 oil and gas companies of India during the period 2012-2019. Our results show that there is no causal relationship between short-term economic indicators and broad stock market indicators and oil and gas stocks. Similarly, we do not find any predictive power of short-term economic indicators. On the other hand we receive support for our hypothesis that stock market indexes cause oil and gas stocks returns. However, in contrast to our hypothesis stock market indexes fail to predict oil and gas stock returns in short-run during our study period.

The reminder of the paper is organized as follows. Section 2 presents literature review and theoretical relationship between index of industrial production, stock markets, and stock returns. In section 3 we present our data and methodology. Section 4 presents empirical results. Section 5 discusses our empirical findings. Finally, section 6 provides a conclusion.

\section{Literature Review}

Over the past few decades, part of the literature has analyzed the relationship between oil prices and stock market returns, while another section of the literature has analyzed the connection between oil prices and index of industrial production. Nevertheless, a small part of the literature has addressed the relationship among industrial production, the stock market indexes and oil and gas stocks returns. Although changes in industrial production is considered an important factor for understanding the movements of stock markets and stock returns, there is still no definitive consensus regarding the relationship between IIP, stock market indexes and individual stock returns.

The role of industrial production as a variable in the determination of stock returns remains an open question, since the results of number of empirical studies do not definitively determine a significant and reliable statistical relationship between them (Bilson et al., 200I; Fama, I98I; Gultekin, I983). However, Chen et al., (1986) identify industrial production as a vital factor for the determination of stock returns, while Cutler et al., (1989) find that stock returns correlate significantly and positively with industrial production growth over the period 1926-1986. Chen (I99I) finds that macro-economic variables help forecast the market premium and future growth of the economy. Stock \& Watson (2003) report that leading economic indicators forecast future performance of stocks returns, however, these forecasts are not consistent. Comincioli (1996) suggests that stock prices do Granger cause economic activity and stock market does predict the economy. Flannery \& Protopapadakis (2002) report that macro-economic variables significantly increase stock market trading and have positive influence on stock returns. Sadorsky (1999) find evidence for influence of oil prices on stock returns. They observed that oil prices and oil price volatility both play important roles in affecting stock returns. Besides, Errunze \& Hogan (I998) conclude that the volatility of industrial production has a negative impact on the stock market. Chen et al., (I986) reveals that industrial production responds positively to shocks in stock returns. Lamont (200I) finds that tracking portfolio returns track the growth rates of economic variable returns. Ewing \& Thompson (2007); Serletis \& Shahmoradi (2005) examine the relationship between industrial production and oil stocks. Balver et al., (I990) show that IIP is able to predict stock returns and find that the relationship between IIP and stock returns is stronger with significant coefficient of determination. Young (2006) finds there to be a statistically significant relationship using the seasonally adjusted index after a lag, with the explanation that increased industrial production leads to increased economic activity, thus resulting in higher earnings for companies. However, Young (2006) find that for the sub-period from 1988-2000 indicate that industrial production can no longer predict stock returns which confirms the US economy's transition from a manufacturing to a service oriented economy. Chan et al., (1998) reports that the macroeconomic factors generally make a poor showing. In Indian context Patel (2012) reports stock market index Granger cause Index of Industrial Production (IIP). In contrast, Singh (20I4) reports that Indian stock market index does not Granger cause Index of Industrial Production. Joshi (2015) reports that Indian stock market influence the IIP.

The goal of this paper is to determine whether IIP relate to oil and gas stock returns and can IIP predict future stock returns. As well as we aim to assess whether relationship holds between stock market indexes and oil and gas stocks returns, and can market indexes predict future stock returns.

\section{Materials and Methods}

\section{I Objectives and Hypotheses}

In this paper we aim to measure causal relationship between economic indicators, stock market indexes and stock prices. To achieve this broad objective, we set specific objectives as, to examine the influence of short-term economic indicators on oil and gas stocks, to measure the impact of stock market indexes on stock returns, to evaluate the predictability of short-term economic indicators and stock market indexes of stock returns, and to understand the contemporaneous relationship among 
oil and gas stocks To validate the objectives set in this paper, we postulate certain hypotheses as $\mathrm{H}_{\mathrm{I}}$ : Short-term economic indicators have significant positive effect on stock returns, $\mathrm{H}_{2}$ : Stock market indexes have significant positive effect on stock returns, $\mathrm{H}_{3}$ : Short term economic indicators have short-term predictive ability of oil and gas stock returns. $\mathrm{H}_{4}$ Stock market indexes have short-term predictive ability of oil and gas stock returns

\subsection{Data and Methodology}

This paper uses a monthly data that spans from April 2012 to March 2019. Using OLS and VAR models, this paper analyzes the relationship among four short-term economic indicators, two stock market indexes, and I0 oil and gas stocks in India. The four short-term economic variables considered in this paper are Index of Industrial Production (IIP), Manufacturing, Mining, Electricity index. Index of industrial production (IIP) has historically been one of the most wellknown and well-used short-term economic performance indicators. The all India IIP is a composite indicator that measures the short-term changes in the volume of production of a basket of industrial products during a given period with respect to that in a chosen base period. The all India IIP provides a single representative figure to measure the general level of industrial activity in the economy on a monthly basis. The IIP is calculated with aggregation of manufacturing, mining, and electricity. Manufacturing has $77.63 \%$ weightage; Mining represents I $4.37 \%$ weightage, and Electricity $7.99 \%$ weightage. Use based classification of IIP is primary goods (34.05\%), capital goods $(8.22 \%)$, intermediate goods (I7.22\%), consumer durables (12.84\%), consumer non-durables (I5.33\%), and infrastructure / construction goods (I2.34\%). The two market indexes that are considered as explanatory variables in this paper are S \& P BSE SENSEX index, BSE Oil \& Gas index. We obtain list of oil and gas stocks from BSE Oil \& Gas Index. This index has I0 oil and gas stocks listed in Bombay Stock Exchange of India (BSE).The 10 oil and gas stocks considered in this paper has 90 per cent of market share in refining, sales and distribution of petroleum products, natural gas, and lubricants. These companies cater oil and gas needs of all market segments in the country. Of these IO stocks seven are public sector units and three are private companies. Four of the public sector units (Bharat Petroleum Corporation Limited (BPCL), Hindustan Petroleum Corporation Limited (HPCL), Indian Oil Corporation (IOC), Oil India Limited (OIL), are in the business of refinery, sales and distribution; two (Gas Authority of India Limited (GAIL), Oil and Natural Gas Corporation (ONGC) are in exploration and refinery of oil and natural gas; and one (Indraprasta Gas Limited, IGL) is in refinery and distribution of natural gas. One of the private companies (Castrol) is in exclusive marketing of lubricants and one (PetroNet) is in production and distribution of natural gas, and the third one (Reliance Industries Limited, RIL) is a conglomerate. We source monthly data of short-term economic indicators from the Indian Government's Ministry of Statistics and Programme Implementation database, whereas, market indexes data and stock prices data are taken from BSE official website. This period (2012-2019) is specifically chosen due to change in base period of short-term economic indicators. In India IIP and related indexes are available since 1937 and the base year changes occasionally to reflect current economic and market conditions. Recent change in base-year happened in 2012. Economic indicators considered in this study are measured on 100 points index, market indexes are measured on free-float market capitalization of index components in points and stock prices are measured in Indian rupee. Initially we run analysis on raw data and later on we calculate log returns of all the variables considered in this paper.

\section{Empirical Results}

Table I reports descriptive statistics of short-term economic indicators and market indexes on their raw data. In five variables Skewness is positive and near to zero and excess Kurtosis values is less than 3, in Electricity index Skewness is negative and excess Kurtosis is less than 3. Depending Skewness and Kurtosis the normality condition is not rejected at 5\% significance level for all the series. We then proceed to check the normality of all series using Jarque-Bera (JB) test. The JB test rejects the hypothesis of normal distribution. From table I we learn that the short-term economic indicators and stock market index is all time low in the year 2012. These indicators reflect the events in international and domestic level during that period. During year 2012 there was sovereign debt crisis in the Euro zone, political uncertainty in Middle East, rise in crude oil prices, and Japan was struck with earthquake are the few to mention. At domestic level the Indian GDP estimation is below 7 per cent, slowdown in policy reforms, domestic demand is lowest in previous ten years. In addition, there is slowdown in the manufacturing and mining sectors, increased gap between demand and supply for electricity which in turn affected the industrial production and exports. All these factors are pertinently captured by short-term economic indicators. On the other hand the short-term economic indicators report highest values in the year 2018. During this period India witnessed GDP of 7.3 per cent, manufacturing sector registered robust growth, revival is seen in investment activity, and witnessed improvement in global demand for Indian products. However, the IIP is slightly hit by gold and jewelers industry due to banking fraud investigated in one of the leading public sector banks. We also notice that along with manufacturing sector, mining and electricity sectors report record growth during this period. 
Table I. Descriptive statistics of raw data

\begin{tabular}{lrrrrrr}
\hline & IIP & Manufacturing & Mining & Electricity & S \& P BSE SENSEX & Oil \& Gas Index \\
\hline Mean & II5.83 & II7.23 & 99.32 & I3I.78 & 26872.70 & I I068.93 \\
Median & II5.40 & I I6.25 & 98.30 & I33.60 & 26833.84 & 9898.69 \\
Maximum & I 40.30 & I40.20 & I32.60 & I67.20 & 38672.91 & 16552.40 \\
Minimum & 98.30 & 99.00 & 82.50 & 94.10 & I62I8.53 & 7587.84 \\
Std. Dev. & I0.3I & I0.09 & II.I4 & 19.10 & 6059.13 & 2629.40 \\
Skewness & 0.30 & 0.28 & 0.80 & -0.10 & 0.09 & 0.57 \\
Kurtosis & $2.3 \mathrm{I}$ & 2.24 & 3.38 & 1.95 & 2.04 & 1.89 \\
Jarque-Bera & 2.97 & 3.13 & 9.43 & 4.02 & 3.34 & 8.79 \\
Probability & 0.23 & 0.21 & 0.01 & 0.13 & 0.19 & 0.01 \\
Observations & 84 & 84 & 84 & 84 & 84 & 84 \\
\hline
\end{tabular}

We first analyze our series by plot the graphs and then draw correlogram to check whether any seasonality or cycles are present in the series. We then perform Hodrick-Prescott Filter test to verify the seasonality. We do not find any seasonality in our series. We then try to identify whether the series are stationary or non-stationary at their level. To verify this, we use three unit-root tests in level by including intercept and trend in the test equation (ADF, ADF-GLS, KPSS) and present results in Table 2. The ADF and ADF-GLS tests for unit root and the null hypothesis is that the series is non-stationary. For the KPSS test the null hypothesis is that the data is stationary. Results present in Table 2 indicate that we cannot reject the null hypothesis of a unit root for all series. All the three tests give similar results and confirm the presence of unit root or non-stationary of data. As unit root is present at level we compute log returns of the data, run descriptive statistics, and the three unit root tests with intercept once again. Table 3 and 4 reports those results. The JB test results confirm the normality of stocks series at 5\% significance level. We re-verified presence of unit root with three tests and if two out of the three tests confirm the presence of a unit root, then it is concluded that the series has a unit root. The unit root tests show that $\log$ return series of market indexes and stocks returns are stationary, therefore, we use log returns in the model for further analysis.

Table 2. Results of stationarity tests on raw data

\begin{tabular}{|c|c|c|c|c|c|}
\hline \multicolumn{3}{|c|}{$\mathrm{ADF}$} & \multicolumn{2}{|c|}{ DF - GLS } & \multirow{2}{*}{$\frac{\text { KPSS }}{\text { LM-Stat }}$} \\
\hline Variable & t-Statistic & Prob. ${ }^{*}$ & t-Statistic & Prob. & \\
\hline IIP & I.09 & 1.00 & 3.33 & 0.00 & I. 28 \\
\hline Manufacturing (Mgf) & 0.90 & 1.00 & 3.35 & 0.00 & I. 28 \\
\hline Mining (Ming) & 0.95 & 1.00 & $-0.3 \mathrm{I}$ & 0.76 & 0.84 \\
\hline Electricity (Elec) & -1.24 & 0.65 & -0.28 & 0.78 & I.09 \\
\hline S\&PSENSEX (BSE) & -0.40 & 0.90 & I.05 & 0.30 & 1.06 \\
\hline Oil\&Gas (O\&G) & -0.80 & $0.8 \mathrm{I}$ & -0.02 & 0.99 & 0.93 \\
\hline BPCL & -1.84 & 0.36 & $-\mathrm{I} .7 \mathrm{I}$ & 0.09 & 0.27 \\
\hline HPCL & -2.02 & 0.28 & -1.86 & 0.07 & 0.30 \\
\hline IOC & $-\mathrm{I} .8 \mathrm{I}$ & 0.37 & $-\mathrm{I} .79$ & 0.08 & 0.25 \\
\hline OIL & -0.69 & 0.84 & -0.56 & 0.58 & 1.05 \\
\hline ONGC & -1.18 & 0.68 & $-\mathrm{I} .15$ & 0.25 & 0.90 \\
\hline Gail & -3.23 & 0.02 & -2.76 & $0.0 \mathrm{I}$ & 0.22 \\
\hline Castrol & -1.79 & 0.38 & -1.03 & 0.30 & 0.42 \\
\hline IGL & -2.25 & 0.19 & -1.96 & 0.05 & $0.4 \mathrm{I}$ \\
\hline PetroNet & -1.73 & $0.4 \mathrm{I}$ & -1.32 & 0.19 & 0.73 \\
\hline Reliance & -2.79 & 0.06 & -1.98 & 0.05 & 0.88 \\
\hline
\end{tabular}


Table 3. Descriptive statistics of log returns

\begin{tabular}{|c|c|c|c|c|c|c|c|c|c|c|}
\hline & & \multicolumn{2}{|l|}{ IIP } & Mgf & \multicolumn{2}{|c|}{ Ming } & Elec & \multicolumn{2}{|c|}{ BSE } & $O \& G$ \\
\hline Mean & & \multicolumn{2}{|l|}{0.42} & $0.4 \mathrm{I}$ & \multicolumn{2}{|c|}{0.35} & 0.53 & \multicolumn{2}{|c|}{0.97} & 0.78 \\
\hline Median & & \multicolumn{2}{|l|}{0.22} & 0.17 & \multicolumn{2}{|c|}{1.02} & 0.88 & \multicolumn{2}{|c|}{ I } & 0.65 \\
\hline Max & & \multicolumn{2}{|l|}{$\mathrm{I} 2.76$} & II.9 & \multicolumn{2}{|c|}{17.84} & 15.52 & \multicolumn{2}{|c|}{9.69} & I 2.82 \\
\hline Min & & \multicolumn{2}{|l|}{-13.49} & -I3.0I & \multicolumn{2}{|c|}{-25.66} & -13.42 & \multicolumn{2}{|c|}{$-7.8 \mathrm{I}$} & -II.96 \\
\hline S D & & \multicolumn{2}{|l|}{5.54} & 5.42 & \multicolumn{2}{|c|}{9.07} & 6.02 & \multicolumn{2}{|c|}{3.93} & 5.43 \\
\hline Skew & & \multicolumn{2}{|l|}{-0.27} & -0.38 & \multicolumn{2}{|c|}{-0.6} & 0.03 & \multicolumn{2}{|c|}{-0.09} & -0.03 \\
\hline Kurt & & \multicolumn{2}{|l|}{3.25} & 3.23 & \multicolumn{2}{|c|}{3.74} & 3.22 & \multicolumn{2}{|c|}{2.5} & 2.8 \\
\hline$J-B$ & & \multicolumn{2}{|l|}{ I. 23} & 2.2 & \multicolumn{2}{|c|}{6.84} & 0.17 & \multicolumn{2}{|c|}{ I } & 0.15 \\
\hline$P$ & & \multicolumn{2}{|l|}{0.54} & 0.33 & \multicolumn{2}{|c|}{0.03} & 0.92 & \multicolumn{2}{|c|}{$0.6 \mathrm{I}$} & 0.93 \\
\hline & BPCL & HPCL & IOC & OIL & Gail & ONG & Castrol & IGL & Petro & RIL \\
\hline Mean & 1.04 & $\mathrm{I} .25$ & 1.08 & -1.09 & 0.06 & -0.63 & 0.35 & 2.34 & $\mathrm{I} .55$ & 1.56 \\
\hline Median & $2 . \mathrm{II}$ & 2.48 & 0.47 & -0.79 & 0.8 & -0.33 & -0.05 & 2.45 & 1.93 & I.I2 \\
\hline Max & 19.79 & 24.14 & 31.76 & 21.05 & 20.35 & 23.94 & 20.84 & 21.35 & I9.2I & 19.79 \\
\hline Min & -30.78 & -28.47 & -19.73 & -48.66 & -33 & $-4 I . I 8$ & $-\mathrm{I} 3.6 \mathrm{I}$ & -17.34 & -I4.76 & -17.01 \\
\hline S D & I0.06 & 10.99 & 8.63 & 9.2 & 9.03 & 9 & $6.7 \mathrm{I}$ & 7.44 & 6.58 & 7.II \\
\hline Skew & $-0.6 \mathrm{I}$ & -0.07 & 0.62 & -I.84 & -0.95 & -0.87 & 0.44 & $0.2 \mathrm{I}$ & 0.02 & 0.22 \\
\hline Kurt & 3.86 & 2.92 & 4.18 & II.5 & 5.77 & 6.73 & $3.7 \mathrm{I}$ & 3.08 & 3 & 3.29 \\
\hline$J-B$ & 7.63 & 0.09 & I0.I5 & 296.85 & 38.94 & 58.48 & 4.45 & 0.66 & $0.0 \mathrm{I}$ & 0.98 \\
\hline$P$ & 0.02 & 0.96 & 0.01 & 0 & 0 & 0 & O.I I & 0.72 & 0.99 & 0.61 \\
\hline Obr & 83 & 83 & 83 & 83 & 83 & 83 & 83 & 83 & 83 & 83 \\
\hline
\end{tabular}

Table 4. Results of stationarity tests on log returns

\begin{tabular}{lrrrrr}
\hline & ADF & & DF - GLS & \multicolumn{2}{c}{ KPSS } \\
\hline Variable & t-Statistic & Prob. & t-Statistic & Prob. & LM-Stat \\
\hline IIP & -4.03 & 0.00 & -0.04 & 0.97 & 0.032 \\
Mgf & $-3.9 \mathrm{I}$ & 0.00 & 0.06 & 0.95 & 0.028 \\
Mining & -3.98 & 0.00 & -0.69 & 0.49 & 0.067 \\
Electricity & -3.86 & 0.00 & -0.27 & 0.79 & 0.025 \\
S \& P SENSEX & $-\mathrm{I} 0.09$ & 0.00 & -1.89 & 0.06 & 0.05 \\
Oil \& Gas & -9.50 & 0.00 & -7.48 & 0.00 & 0.05 \\
BPCL & $-I 0.67$ & 0.00 & -10.10 & 0.00 & 0.269 \\
HPCL & -9.38 & 0.00 & -9.20 & 0.00 & 0.195 \\
IOC & -9.67 & 0.00 & -9.15 & 0.00 & 0.101 \\
OIL & -9.06 & 0.00 & -8.80 & 0.00 & 0.162 \\
ONGC & -8.99 & 0.00 & -8.23 & 0.00 & 0.107 \\
Gail & $-I 0.26$ & 0.00 & -10.05 & 0.00 & 0.076 \\
Castrol & -9.88 & 0.00 & -9.75 & 0.00 & 0.239 \\
IGL & $-\mathrm{II} .10$ & 0.00 & -1.74 & 0.09 & 0.086 \\
PetroNet & -8.13 & 0.00 & -5.50 & 0.00 & 0.124 \\
Reliance & $-\mathrm{I} 0.65$ & 0.00 & -8.29 & 0.00 & 0.396 \\
\hline
\end{tabular}

We then perform cross-order correlation among series and present results in Table 6 . We find significant positive correlation among four short-term economic indicators. We also observe that economic indicators have negative correlation with oil and gas stocks and these correlations are low and statistically insignificant. On the other hand we observe significant positive correlations among $\mathrm{IO}$ oil and gas stocks and these correlations range between 0.82 and 0.22 and statistically significant at 5\% significance level. 
One of our aims in this paper is to measure the influence of short-term economic indicators on oil and gas stocks returns. In order to do this, we regress economic indicators on stocks. Table 7 reports OLS results. From table 7 we learn that there is no significant causation between short-term economic indicators and oil and gas stocks. However, we find significant negative causal relationship between four economic indicators and one of the I0 stocks (GAIL) at I0\% significance level. In one another stock (IOC), Electricity indicator is positively related. Except these two causations economic indicators fail to cause any other oil and gas stocks. Our results indicate that there is no causal relationship between short-term economic indicators and eight oil stocks returns. Our result contradicts that of Comincioli (I996), who suggests that stock market movements Granger cause economic activity. To confirm our OLS results we run pair-wise Granger causality tests and fail to find any causation happening from short-term economic indicators to oil and gas stock returns or from oil and gas stock returns to short-term economic indicators. Granger causality test results confirms the results of cross order correlation and OLS results and indicate that there is no causation between economic indicators and oil and gas stock returns in any direction. Results of pair-wise granger causality are present in Table 5 .

We then employ cross-order correlation between market indexes and stocks. In this paper we use two stock market indexes, one is broad market index (S \& P BSE SENSEX) and the other is sectorial index (S \& P Oil \& Gas). Result of cross-order correlations is present in Table 8. From Table 8, we learn that both the indexes have significant positive correlations with oil and gas stocks returns. Further, these correlations are strong and range between 0.28 and 0.73 and statistically significant at $\mathrm{I} \%$ significance level. Results of cross-order correlations among market indexes and stocks returns are in contrast with our earlier results of cross-order correlation among economic indicators and stocks returns. Our results indicate that there is no correlation among economic indicators and stocks returns. Whereas, we observe significant positive correlation among market indices and oil and gas stocks returns.

Table 5. Pair-wise granger causality tests between IIP and oil and gas stocks

\begin{tabular}{|c|c|c|}
\hline Pairwise Granger Causality Tests & F-Statistic & Prob. \\
\hline IIP does not Granger Cause BPCL & 0.00 & 0.99 \\
\hline BPCL does not Granger Cause IIP & 1.89 & 0.17 \\
\hline IIP does not Granger Cause HPCL & 0.47 & 0.50 \\
\hline HPCL does not Granger Cause IIP & 0.62 & 0.43 \\
\hline IIP does not Granger Cause IOC & $0.3 \mathrm{I}$ & 0.58 \\
\hline IOC does not Granger Cause IIP & 1.26 & 0.27 \\
\hline IIP does not Granger Cause OIL & 0.01 & $0.9 \mathrm{I}$ \\
\hline OIL does not Granger Cause IIP & 0.42 & 0.52 \\
\hline IIP does not Granger Cause GAIL & 0.43 & 0.52 \\
\hline GAIL does not Granger Cause IIP & 1.68 & 0.20 \\
\hline IIP does not Granger Cause ONGC & 0.15 & 0.70 \\
\hline ONGC does not Granger Cause IIP & 3.49 & 0.07 \\
\hline IIP does not Granger Cause CASTROL & 0.97 & 0.33 \\
\hline CASTROL does not Granger Cause IIP & 0.59 & 0.44 \\
\hline IIP does not Granger Cause PETRO & 0.16 & 0.69 \\
\hline PETRO does not Granger Cause IIP & 0.03 & 0.87 \\
\hline IIP does not Granger Cause RIL & $0.0 \mathrm{I}$ & 0.94 \\
\hline RIL does not Granger Cause IIP & 0.36 & 0.55 \\
\hline IIP does not Granger Cause IGL & 0.18 & 0.68 \\
\hline IGL does not Granger Cause IIP & 0.63 & 0.43 \\
\hline
\end{tabular}

From cross-order correlations among market index, sectorial index and stocks returns we learn that these correlations are moderate, thus suggesting that multicollinearity should not be an issue during the estimation process. In continuation to correlation analysis, we run bivariate OLS regression between each market indicator and individual oil and gas stocks returns. Results present in Table 9. From the results in Table 9 we find that both market index and sectorial index cause stocks at I\% significance level. The results of causality test indicate that coefficients range between 0.55 and I.2I and $\mathrm{r}^{2}$ value range between 0.10 and 0.37 . These results suggest that broad market index and sectorial index have explanatory power about the variability in stock returns for contemporaneous period. 
Table 6. Cross-order correlations among short-term economic indicators and oil and gas stocks

\begin{tabular}{|c|c|c|c|c|c|c|c|c|c|c|c|c|c|c|}
\hline Variable & IIP & Mgf & Mining & Elec & BPCL & Castrol & Gail & HPCL & IGL & IOC & OIL & ONGC & Petro & RIL \\
\hline IIP & I & & & & & & & & & & & & & \\
\hline Mgf & $.99^{m+m}$ & I & & & & & & & & & & & & \\
\hline Mining & $.86^{\text {tot }}$ & $.80^{* *+}$ & I & & & & & & & & & & & \\
\hline Elec & $.62^{\text {wh }}$ & $.57^{\text {sos }}$ & $.44^{\text {sit }}$ & I & & & & & & & & & & \\
\hline BPCL & .10 & .08 & .I I & .18 & I & & & & & & & & & \\
\hline CASTROL & .10 & .I I & .02 & .05 & .18 & I & & & & & & & & \\
\hline GAIL & -.20 & -.18 & -.18 & -.20 & $.36^{*+4}$ & .04 & I & & & & & & & \\
\hline HPCL & .I I & .10 &. $\mathrm{II}$ & .15 & $.8 \mathrm{I}^{*+4}$ & $.32^{*+*}$ & $.3 \mathrm{I}^{\text {曲 }}$ & I & & & & & & \\
\hline IGL & -.02 & .00 & -.08 & -.04 & .16 & $.42^{\text {wn }}$ & $.37^{\text {sos }}$ & $.29^{m+\infty}$ & $\mathrm{I}$ & & & & & \\
\hline IOC &. $\mathrm{II}$ &.$I I$ & .04 & $.22^{*}$ & $.6 \mathrm{I}^{\mathrm{ma}}$ & .20 & $.24^{*}$ & $.72^{* *}$ & $.25^{*}$ & I & & & & \\
\hline OIL & -.13 & -.12 & -.16 & -.03 & .18 & $.0 \mathrm{I}$ & $.39^{+*+\infty}$ & .19 & $.35^{\text {sta }}$ & $.22^{*}$ & I & & & \\
\hline ONGC & -.04 & -.05 & -.04 & .12 & $.47^{\text {son }}$ & .17 & $.4 \mathrm{I}^{\text {必 }}$ & $.39^{\text {w. }}$ & $.25^{*}$ & $.3 \mathrm{I}^{\text {加 }}$ & $.4 \mathrm{I}^{* \alpha}$ & I & & \\
\hline PETRO & -.03 & -.03 & -.06 & .06 & $.24^{*}$ & $.28^{*}$ & $.42^{+*}$ & $.33^{m}$ & $.49^{\text {sin }}$ & $.29^{m+*}$ & $.27^{*}$ & $.35^{5 * t}$ & I & \\
\hline RIL & -.07 & -.06 & -.12 & .02 & $.24^{*}$ & .14 & $.26^{*}$ & .16 & $.32^{\text {sik }}$ & $.25^{*}$ & $.33^{3 x}$ & $.29^{+* x}$ & $.23^{*}$ & I \\
\hline
\end{tabular}

. Correlation is significant at the 0.0I level (2-tailed). Correlation is significant at the 0.05 level (2-tailed).

Table 7. Contemporaneous Causal Relation among short-term economic indicators and oil and gas stocks

\begin{tabular}{|c|c|c|c|c|c|c|c|c|c|c|c|c|c|c|c|c|}
\hline \multirow{2}{*}{$\begin{array}{l}\text { Index } \\
\text { Stock }\end{array}$} & \multicolumn{4}{|c|}{ IIP } & \multicolumn{4}{|c|}{ Mining } & \multicolumn{4}{|c|}{ Manufacturing } & \multicolumn{4}{|c|}{ Electricity } \\
\hline & Beta & $\mathrm{R} 2$ & $\mathrm{~F}$ & Sig. & Beta & $\mathrm{R} 2$ & $\mathrm{~F}$ & Sig. & Beta & $\mathrm{R} 2$ & $\mathrm{~F}$ & Sig. & Beta & $\mathrm{R} 2$ & $\mathrm{~F}$ & Sig. \\
\hline BPCL & 0.19 & $0.0 \mathrm{I}$ & 0.89 & 0.35 & 0.13 & $0.0 \mathrm{I}$ & 1.07 & 0.30 & 0.15 & $0.0 \mathrm{I}$ & 0.54 & 0.47 & $0.3 \mathrm{I}$ & 0.03 & 2.82 & 0.10 \\
\hline HPCL & 0.23 & $0.0 \mathrm{I}$ & I.I4 & 0.29 & 0.13 & $0.0 \mathrm{I}$ & I.OI & 0.32 & $0.2 \mathrm{I}$ & $0.0 \mathrm{I}$ & 0.90 & 0.35 & 0.27 & 0.02 & I.87 & 0.18 \\
\hline IOC & 0.18 & 0.01 & I.I2 & 0.29 & 0.04 & 0.00 & 0.14 & $0.7 \mathrm{I}$ & 0.18 & $0.0 \mathrm{I}$ & 1.00 & 0.32 & 0.32 & 0.05 & 4.20 & 0.04 \\
\hline OIL & -0.22 & 0.02 & I.5I & 0.22 & -0.17 & 0.03 & 2.38 & 0.13 & -0.22 & 0.02 & 1.33 & 0.25 & -0.06 & 0.00 & 0.12 & 0.73 \\
\hline ONGC & -0.07 & 0.00 & 0.13 & 0.72 & -0.04 & 0.00 & 0.15 & 0.70 & -0.10 & 0.00 & 0.28 & 0.60 & 0.19 & 0.02 & $\mathrm{I} .38$ & 0.24 \\
\hline Gail & -0.33 & 0.04 & 3.43 & 0.07 & -0.18 & 0.03 & 2.77 & 0.10 & -0.31 & 0.03 & $2.9 \mathrm{I}$ & 0.09 & -0.30 & 0.04 & 3.39 & 0.07 \\
\hline IGL & -0.03 & 0.00 & 0.03 & 0.86 & -0.07 & $0.0 \mathrm{I}$ & 0.65 & 0.42 & 0.00 & 0.00 & 0.00 & 0.98 & -0.05 & 0.00 & 0.14 & $0.7 \mathrm{I}$ \\
\hline Castrol & 0.12 & $0.0 \mathrm{I}$ & 0.85 & 0.36 & 0.02 & 0.00 & 0.06 & $0.8 \mathrm{I}$ & 0.15 & $0.0 \mathrm{I}$ & I.I4 & 0.29 & 0.06 & 0.00 & 0.23 & 0.63 \\
\hline PetroNet & -0.04 & 0.00 & $0 . \mathrm{II}$ & 0.74 & -0.04 & 0.00 & 0.29 & 0.59 & -0.05 & 0.00 & 0.12 & 0.73 & 0.07 & 0.00 & 0.29 & 0.59 \\
\hline Reliance & -0.09 & 0.00 & 0.40 & 0.53 & -0.09 & $0.0 \mathrm{I}$ & I.I8 & 0.28 & -0.08 & 0.00 & 0.34 & 0.56 & 0.03 & 0.00 & 0.05 & 0.83 \\
\hline
\end{tabular}


Table 8. Cross-order correlation among stock market indexes and oil and gas stocks returns

\begin{tabular}{|c|c|c|c|c|c|c|c|c|c|c|c|c|}
\hline & BSE SENSEX & OilGas & $\mathrm{BPCL}$ & HPCL & IOC & OIL & Gail & ONGC & Castrol & IGL & Petro & RIL \\
\hline BSESENSEX & I & & & & & & & & & & & \\
\hline OilGas & $.72^{* * *}$ & I & & & & & & & & & & \\
\hline BPCL & $.47^{\text {sht }}$ & $.65^{\text {th }}$ & $\mathrm{I}$ & & & & & & & & & \\
\hline HPCL & $.43^{\text {th }}$ & $.6 \mathrm{I}^{\text {th }}$ & $.8 \mathrm{I}^{*+*}$ & I & & & & & & & & \\
\hline IOC & $.33^{+\infty}$ & $.63^{+\infty}$ & $.6 \mathrm{I}^{m+\infty}$ & $.72^{m+*}$ & I & & & & & & & \\
\hline OIL & $.33^{\hbar+}$ & $.43^{\text {th }}$ & .18 & .19 & $.22^{*}$ & I & & & & & & \\
\hline Gail & 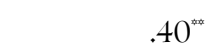 & $.55^{\text {tot }}$ & $.36^{* \ldots+4}$ & $.3 \mathrm{I}^{\ldots+4}$ & $.24^{*}$ & $.39^{*+*}$ & I & & & & & \\
\hline ONGC & $.5 \mathrm{I}^{\ldots+*}$ & $.65^{\text {thx }}$ & $.47^{\text {sto }}$ & $.39^{m+n}$ & $.30^{\text {son }}$ & $.40^{+\infty *+1}$ & $.4 \mathrm{I}^{*+*}$ & I & & & & \\
\hline Castrol & $.32^{\text {son }}$ & $.27^{*}$ & .18 & $.32^{\text {sit }}$ & .20 & $.0 \mathrm{I}$ & .04 & .17 & I & & & \\
\hline IGL & $.44^{*+*}$ & $.45^{\text {ss }}$ & .16 & $.29^{m+n}$ & $.25^{*}$ & $.34^{*+*}$ & $.36^{*+*}$ & $.24^{*}$ & $.42^{+\infty}$ & I & & \\
\hline Petro & $.35^{\text {st }}$ & $.45^{\text {bx }}$ & $.24^{*}$ & $.33^{\ldots+}$ & $.29^{m+n}$ & $.22^{*}$ & $.42^{\text {st }}$ & $.35^{\text {sen }}$ & $.27^{*}$ & $.49^{\text {sta }}$ & I & \\
\hline RIL & $.6 I^{m * n}$ & $.7 \mathrm{I}^{\text {sto }}$ & $.24^{*}$ & .16 & $.25^{*}$ & $.33^{m+x}$ & $.26^{*}$ & $.29^{m+x}$ &. $\mathrm{I} 4$ & $.3 \mathrm{I}^{*+*}$ & $.22^{*}$ & I \\
\hline
\end{tabular}

Table 9. Contemporaneous causal relationship among stock market indexes and oil and gas stocks returns

\begin{tabular}{|c|c|c|c|c|c|c|c|c|}
\hline \multirow{2}{*}{$\frac{\text { Explanatory variable }}{\text { Stock }}$} & \multicolumn{4}{|c|}{ BSE SENSEX } & \multicolumn{4}{|c|}{ Oil \& Gas } \\
\hline & Beta & $\mathrm{R} 2$ & $\mathrm{~F}$ & Sig. & Beta & $\mathrm{R} 2$ & $\mathrm{~F}$ & Sig. \\
\hline BPCL & $\mathrm{I} .2 \mathrm{I}$ & 0.22 & $23.5 \mathrm{I}$ & 0.00 & I. 20 & 0.42 & 59.18 & 0.00 \\
\hline HPCL & $\mathrm{I} .2 \mathrm{I}$ & 0.19 & 18.72 & 0.00 & I. 24 & 0.37 & $48.1 \mathrm{I}$ & 0.00 \\
\hline IOC & 0.73 & O.I I & 9.97 & 0.00 & 1.00 & 0.40 & 53.21 & 0.00 \\
\hline OIL & 0.79 & O.I I & 10.29 & 0.00 & 0.74 & 0.19 & I8.94 & 0.00 \\
\hline ONGC & I.I8 & 0.27 & 29.47 & 0.00 & 1.09 & 0.43 & 62.04 & 0.00 \\
\hline Gail & 0.92 & 0.16 & I 5.56 & 0.00 & 0.93 & $0.3 \mathrm{I}$ & 36.33 & 0.00 \\
\hline IGL & 0.84 & 0.20 & 20.13 & 0.00 & 0.62 & $0.2 \mathrm{I}$ & 21.13 & 0.00 \\
\hline Castrol & 0.55 & 0.10 & 9.38 & 0.00 & 0.34 & 0.08 & $6.6 \mathrm{I}$ & $0.0 \mathrm{I}$ \\
\hline PetroNet & 0.60 & 0.13 & II.98 & 0.00 & 0.55 & $0.2 \mathrm{I}$ & 21.33 & 0.00 \\
\hline Reliance & I.I I & 0.37 & 48.49 & 0.00 & 0.93 & $0.5 \mathrm{I}$ & 83.18 & 0.00 \\
\hline
\end{tabular}


As we find causal relationship between market indexes and oil and gas stocks returns, we are curious to know whether these two market indexes can help predict short-term returns of oil and gas stocks. To know this we relate current returns of stocks with one-lag of market indexes. By doing this our objective is to assess the short-term predictability of market indexes of stock returns. Results are present in Table IO. To our surprise we do not find any predictability of S \& P BSE SENSEX and S \& P Oil \& Gas indexes of stock returns. This result indicates that current month market movement has no predictive power of next month stock returns. We make line estimation of S \& P BSE SENSEX on all the IO stocks and present in Figure I. From Figure I it is clearly evident that market index fails to predict next month stock returns and we also observe that observations scatter far away from estimation line.

Table 10. Predictive Regression of stock market indexes of oil and gas stocks

\begin{tabular}{l|cccc|cccc}
\hline Explanatory Variable & \multicolumn{4}{|c|}{ BSE SENSEX } & \multicolumn{4}{c}{ Oil \& Gas } \\
\hline \multicolumn{1}{c|}{ Stock } & Beta & R2 & F & Sig. & Beta & R2 & F & Sig. \\
\hline BPCL & 0.00 & 0.00 & 0.00 & I.00 & -0.20 & 0.01 & 0.90 & 0.35 \\
HPCL & 0.18 & 0.00 & $0.3 \mathrm{I}$ & 0.58 & 0.05 & 0.00 & 0.04 & 0.84 \\
IOC & 0.24 & 0.01 & 0.92 & 0.34 & 0.04 & 0.00 & 0.05 & 0.82 \\
OIL & $0.2 \mathrm{I}$ & 0.01 & 0.63 & 0.43 & 0.25 & 0.02 & 1.73 & 0.19 \\
ONGC & 0.10 & 0.00 & 0.14 & 0.70 & 0.04 & 0.00 & 0.05 & 0.83 \\
Gail & -0.04 & 0.00 & 0.02 & 0.89 & -0.02 & 0.00 & 0.02 & 0.90 \\
IGL & -0.35 & 0.03 & $2.8 \mathrm{I}$ & 0.10 & -0.04 & 0.00 & 0.06 & 0.80 \\
Castrol & $0.1 \mathrm{I}$ & 0.00 & 0.30 & 0.59 & 0.07 & 0.00 & 0.27 & 0.61 \\
PetroNet & 0.32 & 0.04 & 2.92 & 0.09 & 0.35 & 0.08 & 7.24 & 0.01 \\
Reliance & -0.18 & 0.01 & 0.80 & 0.37 & -0.26 & 0.04 & 3.09 & 0.08 \\
\hline
\end{tabular}

Then we proceed for VAR model analysis. The Vector Autoregressive (VAR) model is usually employed for the purpose of forecasting systems of interconnected time series and studying the dynamic effects on the system of series arising from arbitrary disturbances. The VAR approach considers each variable to be endogenous in the model as a function of all endogenous variables lagged values, as a result of which the need for structural modeling is bypassed. The auto regressive term happens because of the appearance of the dependent variables lagged values on the right side of the model and because of the fact that a vector of two or more variables is included in the model, the vector term takes place (Fayyad \& Dally, 20II). One of the main strengths of the VAR model is that it enables us to compute the dynamic relationships between the investigated variables.

To further investigate the causal relationship among market indexes and stocks we estimate a VAR model. As we are interested in short-term causal relationships we use lag equal to I in our VAR model. Table I I displays the results of an unrestricted VAR model. Result of LM test shows evidence of no autocorrelation problem in the model. Results indicate that stocks have a negative and statistically significant influence of S \& P BSE SENSEX and S \& P Oil \& Gas indexes at I0\% significance level. This result indicates that following month of increase or decrease in stock returns the markets decrease or increase. However, we learn that the coefficients are very weak. To confirm these results we run Granger causality tests and find that no causality happens between study variables. As there is no causality in any direction between the variables, the estimation results indicate no predictive power of market indicators of stock prices. Pair-wise granger causality test results are present in Table $\mathrm{I} 2$. 

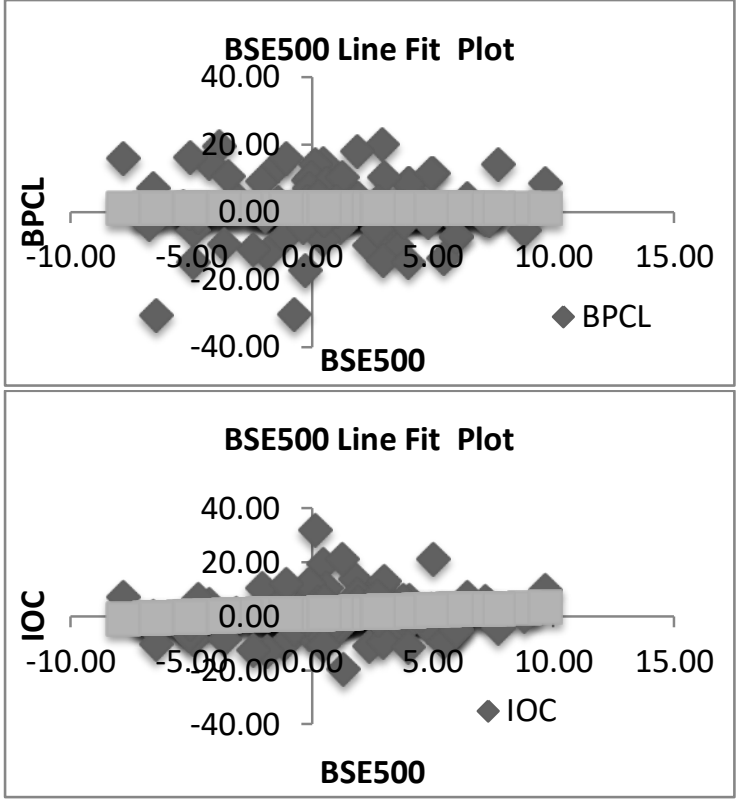

\section{BSE500 Line Fit Plot}
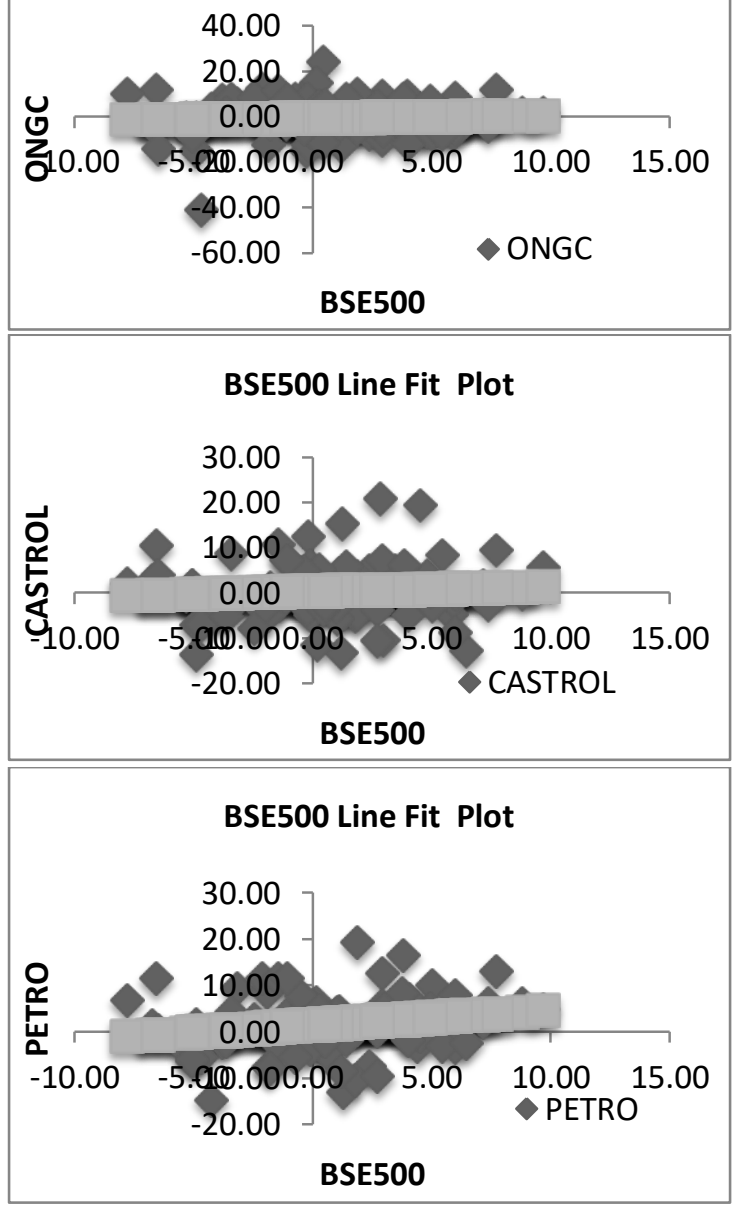
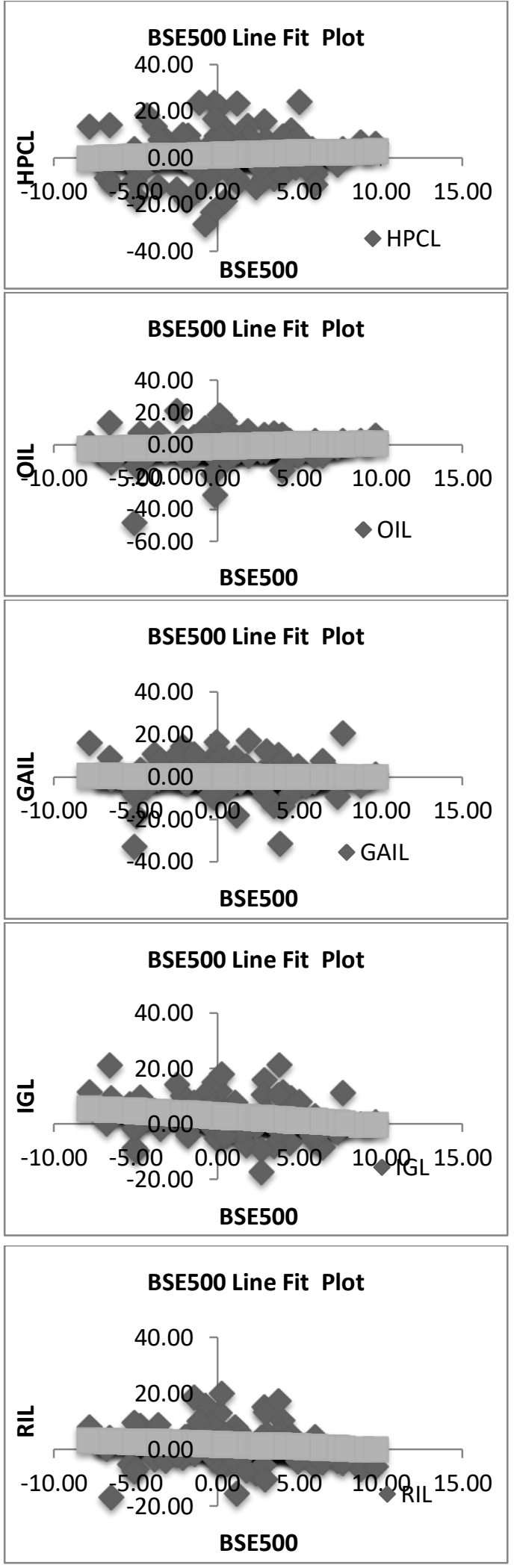

Figure I. Line estimations of stock market indexes of oil and gas stocks 
Table I I. VAR Results between stock market indexes and oil and gas stocks

\begin{tabular}{|c|c|c|c|c|c|c|c|}
\hline & SENSEX & OIL_GAS & BPCL & & SENSEX & OIL_GAS & HPCL \\
\hline SENSEX(-I) & 0.07 & 0.09 & 0.40 & $\operatorname{SENSEX}(-\mathrm{I})$ & 0.07 & 0.08 & 0.26 \\
\hline Sig. & -0.16 & -0.22 & $-0.4 \mathrm{I}$ & Sig. & -0.16 & -0.22 & -0.46 \\
\hline OIL_GAS(-I) & $-0.2 \mathrm{I}$ & 0.04 & -0.16 & OIL_GAS(-I) & -0.18 & 0.03 & 0.07 \\
\hline Sig. & -0.13 & -0.18 & -0.34 & Sig. & -0.13 & -0.18 & -0.37 \\
\hline $\operatorname{BPCL}(-\mathrm{I})$ & 0.02 & -0.14 & -0.20 & $\operatorname{HPCL}(-\mathrm{I})$ & -0.01 & -0.12 & -0.13 \\
\hline \multirow[t]{2}{*}{ Sig. } & $-0.06^{*}$ & $-0.08^{*}$ & -0.15 & Sig. & $-0.05^{\star}$ & $-0.07^{*}$ & -0.14 \\
\hline & SENSEX & OIL_GAS & IOC & & SENSEX & OIL_GAS & OIL \\
\hline SENSEX(-I) & 0.08 & 0.04 & 0.32 & $\operatorname{SENSEX}(-\mathrm{I})$ & 0.07 & 0.08 & -0.07 \\
\hline Sig. & -0.16 & -0.23 & -0.37 & Sig. & -0.16 & -0.22 & -0.38 \\
\hline OIL_GAS(-I) & -0.20 & 0.00 & $0.0 \mathrm{I}$ & OIL_GAS(-I) & -0.17 & -0.17 & 0.36 \\
\hline Sig. & -0.14 & -0.20 & -0.32 & Sig. & -0.12 & -0.17 & -0.29 \\
\hline $\mathrm{IOC}(-\mathrm{I})$ & $0.0 \mathrm{I}$ & -0.09 & -0.14 & OIL(-I) & -0.03 & 0.07 & -0.10 \\
\hline \multirow[t]{2}{*}{ Sig. } & $-0.07^{\star}$ & $-0.09 *$ & -0.15 & Sig. & $-0.05^{*}$ & $-0.07^{*}$ & -0.12 \\
\hline & SENSEX & OIL_GAS & ONGC & & SENSEX & OIL_GAS & Gail \\
\hline SENSEX(-I) & 0.07 & 0.08 & 0.13 & SENSEX(-I) & 0.07 & 0.09 & -0.02 \\
\hline Sig. & -0.16 & -0.23 & -0.38 & Sig. & -0.16 & -0.22 & -0.37 \\
\hline OIL_GAS(-I) & -0.18 & -0.15 & 0.02 & OIL_GAS(-I) & -0.25 & -0.12 & 0.17 \\
\hline Sig. & -0.13 & -0.19 & $-0.3 \mathrm{I}$ & Sig. & -0.12 & -0.18 & -0.30 \\
\hline ONGC(-I) & -0.01 & 0.03 & -0.04 & GAIL $(-\mathrm{I})$ & 0.06 & 0.00 & -0.19 \\
\hline \multirow[t]{2}{*}{ Sig. } & $-0.06^{*}$ & $-0.09 *$ & -0.15 & Sig. & $-0.06^{*}$ & $-0.08^{*}$ & -0.14 \\
\hline & SENSEX & OIL_GAS & IGL & & SENSEX & OIL_GAS & Castrol \\
\hline SENSEX(-I) & 0.06 & 0.07 & -0.54 & SENSEX(-I) & 0.08 & 0.12 & 0.13 \\
\hline Sig. & -0.16 & -0.23 & -0.30 & Sig. & -0.16 & -0.23 & -0.28 \\
\hline OIL_GAS(-I) & -0.20 & -0.13 & 0.36 & OIL_GAS(-I) & -0.18 & $-0 . \mathrm{II}$ & 0.05 \\
\hline Sig. & -0.12 & -0.17 & -0.22 & Sig. & $-0.1 \mathrm{I}$ & -0.16 & -0.20 \\
\hline $\operatorname{IGL}(-\mathrm{I})$ & 0.03 & 0.03 & -0.18 & CASTROL(-I) & -0.03 & -0.07 & -0.14 \\
\hline \multirow[t]{2}{*}{ Sig. } & $-0.07^{\star *}$ & $-0.09^{*}$ & -0.12 & Sig. & $-0.07^{\star *}$ & $-0.10^{*}$ & -0.12 \\
\hline & SENSEX & OIL_GAS & Petronet & & SENSEX & OIL_GAS & Reliance \\
\hline SENSEX(-I) & 0.06 & 0.08 & -0.06 & SENSEX(-I) & 0.10 & 0.06 & 0.18 \\
\hline Sig. & -0.16 & -0.22 & -0.26 & Sig. & -0.16 & -0.23 & -0.29 \\
\hline OIL_GAS(-I) & -0.22 & -0.19 & 0.40 & OIL_GAS(-I) & -0.14 & -0.18 & -0.26 \\
\hline Sig. & -0.12 & -0.17 & -0.20 & Sig. & -0.13 & -0.19 & -0.24 \\
\hline $\operatorname{PETRO}(-\mathrm{I})$ & 0.07 & 0.14 & -0.04 & RIL(-I) & -0.07 & 0.08 & -0.10 \\
\hline Sig. & $-0.07^{*}$ & $-0.10^{*}$ & -0.12 & Sig. & $-0.09^{*}$ & -0.12 & -0.16 \\
\hline
\end{tabular}

Table I2. Pair-wise Granger causality test results between stock market indexes and oil and gas stocks.

\begin{tabular}{lrr}
\hline \multicolumn{1}{c}{ Panel A: Pairwise Granger Causality Tests (SENSEX vs. Stock returns) } & F-Statistic & 0.58 \\
\hline BPCL does not Granger Cause SENSEX & 0.30 & 0.39 \\
SENSEX does not Granger Cause BPCL & 0.75 & 0.38 \\
HPCL does not Granger Cause SENSEX & 0.76 & 0.37 \\
SENSEX does not Granger Cause HPCL & 0.80 & $0.4 \mathrm{I}$ \\
IOC does not Granger Cause SENSEX & 0.68 & $0.2 \mathrm{I}$ \\
SENSEX does not Granger Cause IOC & 1.60 & 0.32 \\
OIL does not Granger Cause SENSEX & 1.02 & 0.38 \\
SENSEX does not Granger Cause OIL & 0.78 & 0.79 \\
GAIL does not Granger Cause SENSEX & 0.07 & 0.7
\end{tabular}


SENSEX does not Granger Cause GAIL

ONGC does not Granger Cause SENSEX

SENSEX does not Granger Cause ONGC

IGL does not Granger Cause SENSEX

SENSEX does not Granger Cause IGL

CASTROL does not Granger Cause SENSEX

SENSEX does not Granger Cause CASTROL

PETRO does not Granger Cause SENSEX

SENSEX does not Granger Cause PETRO

RIL does not Granger Cause SENSEX

\begin{tabular}{lcc}
\hline Panel B: Pairwise Granger Causality Tests (Oil \& Gas Index Vs. Stock Returns) & F-Statistic & Prob. \\
\hline BPCL does not Granger Cause OIL_GAS & 3.14 & 0.08 \\
OIL_GAS does not Granger Cause BPCL & 0.02 & 0.88 \\
HPCL does not Granger Cause OIL_GAS & 2.90 & 0.09 \\
OIL_GAS does not Granger Cause HPCL & 0.52 & 0.47 \\
IOC does not Granger Cause OIL_GAS & 1.05 & $0.3 \mathrm{I}$ \\
OIL_GAS does not Granger Cause IOC & $0.8 \mathrm{I}$ & 0.37 \\
OIL does not Granger Cause OIL_GAS & 0.91 & 0.34 \\
OIL_GAS does not Granger Cause OIL & $2.3 \mathrm{I}$ & 0.13 \\
GAIL does not Granger Cause OIL_GAS & 0.00 & 0.99 \\
OIL_GAS does not Granger Cause GAIL & 0.45 & 0.50 \\
ONGC does not Granger Cause OIL_GAS & 0.14 & $0.7 \mathrm{I}$ \\
OIL_GAS does not Granger Cause ONGC & $0.1 \mathrm{I}$ \\
IGL does not Granger Cause OIL_GAS & 0.19 & 0.74 \\
OIL_GAS does not Granger Cause IGL & 0.38 & 0.66 \\
CASTROL does not Granger Cause OIL_GAS & 0.45 & 0.54 \\
OIL_GAS does not Granger Cause CASTROL & 0.62 & $0.5 \mathrm{I}$ \\
PETRO does not Granger Cause OIL_GAS & 1.93 & 0.43 \\
OIL_GAS does not Granger Cause PETRO & 6.52 & 0.17 \\
RIL does not Granger Cause OIL_GAS & 0.55 & 0.79 \\
OIL_GAS does not Granger Cause RIL & & 0.46 \\
\hline
\end{tabular}

\section{Discussion}

In this paper we observe that stock market movements cause stock returns in contemporaneous periods. Our results indicate that there is positive correlation between stock market movements and oil and gas stock returns, when stock markets increase stock prices of oil and stock prices also increase and vice-versa. However, we fail to find any predictive ability of stock market indexes in short term of oil and gas stock returns. Our predictive regression analysis reveals insignificant coefficient of determination and not able explain the variability of market indexes of stock returns. Our VAR models and Granger cause models also do not provide any significant evidence for predictability of stock market indexes of stock returns. On the other side, we do not find any correlation or causation between short-term economic indicators and stock market indexes. Our results are in contrast to results reported by Cutler et al., (I989); Chen et al., (1986) who find significant positive correlation between industrial production and stock market returns. In the Indian context our results are similar to those of Singh (2014) who reports no causation between IIP and stock market indexes. From our results we interpret that Indian stock markets and returns of oil and gas stocks are independent from industrial production. Even though the Indian manufacturing, mining, and electricity sectors are closely knitted with oil and gas industry, their impact on oil and gas stock returns is minimal. This is because financial performance and profitability of oil and gas companies are regulated by Government of India's policy decisions. Seventy percent of the oil and gas stocks studied in this paper are owned and controlled by government and are still under government policy regulations. In addition, as these companies import crude oil, global level factors like crude oil prices, exchange rate fluctuations, demand and supply of crude oil may 
have significant impact. As a coincident economic indicator industrial production rightly reflect Indian economic situation but not able to influence the stock market indexes which are leading economic indicators.

\section{Conclusion}

The aim of this paper is four fold: i) to examine the influence of short-term economic indicators on stock prices ii) to investigate the impact of market indexes on oil and gas stocks; iii) to predict stock returns using economic and market indicators; iv) to study the relationship among stock prices of Indian oil and gas companies over the period 2012-2019. We consider four short-term economic indicators, two stock market indexes and IO Indian oil and gas companies. We find no causal relation between short-term economic indicators and stock market indexes. Similarly, we do not find any causation between short-term economic indicators and oil and gas stocks. These results indicate that stock markets and oil and gas stocks are independent from industrial production. On the other side we find significant positive correlation and causation between stock market indexes and stock returns. However, in contrast to this we fail to find any and predictive power of stock market indexes about stock returns in short run. Leading economic indicators have contemporaneous relationship with stock returns, but are not able to predict the stock returns in short run. We conclude that industrial production will not help predict neither stock market movements nor stock returns. Our empirical results suggest that stock market indexes help to understand contemporaneous stock returns but not future returns. In this paper we measure the impact of domestic economic indicators and ignored the global factors. Future research can consider the influence of crude oil prices, and exchange rate fluctuations on oil and gas stocks returns. Furthermore, future research can link monthly economic indicator values with quarterly financial results of oil and gas companies.

\section{References}

Bilson, C. M., Brailsford, T. J., \& Hooper, V. J. (200I). Selecting macroeconomic variables as explanatory factors of emerging stock market returns. Pacific-Basin Finance Joumal, 9(4), 40I-426.

Balvers, R. J., Cosimano, T. F., \& McDonald, B. (1990). Predicting stock returns in an efficient market. The Journal of Finance, 45(4), I109-II28.

Comincioli, B. (1996). The stock market as a leading indicator: An application of granger causality. University avenue undergraduate journal of economics, $I(\mathrm{I})$, I.

Chan, L. K., Karceski, J., \& Lakonishok, J. (1998). The risk and return from factors. Journal of financial and quantitative analysis, 33(2), I59-I88.

Chen, N. F. (I99I). Financial investment opportunities and the macroeconomy. The Journal of Finance, 46(2), 529-554.

Chen, N. F., Roll, R., \& Ross, S. A. (1986). Economic forces and the stock market. Journal of business, 59(3), 383-403.

Cutler, D. M., Poterba, J. M., \& Summers, L. H. (1989). What Moves Stock Prices? Massachusetts Institute of Technology (MIT), Department of Economics, Working papers. I5. I0.3905/jpm.1989.4092I2

Errunza, V. \& Hogan, K. (1998). Macroeconomic determinants of European Stock Market volatility. Journal of European Financial Management, 4(3), 36I-77.

Ewing, B. T., \& Thompson, M. A. (2007). Dynamic cyclical comovements of oil prices with industrial production, consumer prices, unemployment, and stock prices. Energy Policy, 35(II), 5535-5540.

Fama, E. F. (I98I). Stock returns, real activity, inflation, and money. The American economic review, 7I(4), 545-565.

Flannery, M. J., \& Protopapadakis, A. A. (2002). Macroeconomic factors do influence aggregate stock returns. The review of financial studies, I5(3), 75I-782.

Gultekin, N. B. (1983). Stock market returns and inflation: evidence from other countries. The Journal of Finance, 38(I), $49-65$.

Stock, J. H., \& Watson, M. W. (2003). How did leading indicator forecasts perform during the 200I recession?. FRB Richmond Economic Quarterly, 89(3), 7I-90.

Joshi, S. (2015). Correlation and causality between stock market and economy: Evidence from India. International Journal of Multidisciplinary Research and Development, 2(5), I2I-I27.

Lamont, O. A. (200I). Economic tracking portfolios. Joumal of Econometrics, I05(I), I6I-I84.

Patel, S. (2012). The effect of macroeconomic determinants on the performance of the Indian stock exchange. Management Review Journal 22, II7-27.

Sadorsky, P. (I999). Oil price shocks and stock market activity. Energy Economics, 21, 449-469.

Serletis, A., \& Shahmoradi, A. (2005). Business cycles and natural gas prices. OPEC review, 29 (I), 75-84.

Singh, P. (2014). An empirical relationship between selected Indian stock market indices and macroeconomic indicators. International Journal of Research in Business Management 2(9), 8I-92.

Young, P. (2006). Industrial production and stock returns (Doctoral dissertation, Faculty of Business AdministrationSimon Fraser University).

\section{Copyrights}

Copyright for this article is retained by the author(s), with first publication rights granted to the journal. This is an openaccess article distributed under the terms and conditions of the Creative Commons Attribution license (http://creativecommons.org/licenses/by/4.0/). 